\title{
Control of two-spotted spider mite, Tetranychus urticae Koch (Acari: Tetranychidae) by predators on potted plants
}

Mst. Mursalin Parvin and Mohd. Mainul Haque

Department of Zoology, University of Rjshahi, Rajshahi -6205, Bangladesh.

\begin{abstract}
Three predators Scolothrips sexmaculatus Pergande, Phytoseiulus persimilis Athias - Henriot and Stethorus punctillum Weise were used to control two-spotted spider mite, Tetranychus urticae Koch on potted bean plants. Mite population increased exponentially on the untreated plants, but on the predator treated plants, increase of mite population was checked and remained within minimum number. Early release of predator checked the mite population earlier and kept it lower than on late released plants. All the three predators may be used as bio-control agents against two-spotted spider mite.
\end{abstract}

Key words: Control, Tetranychus urticae, Scolothrips sexmaculatus, Phytoseiulus persimilis, Stethorus punctillum and bio-control agents.

\section{Introduction}

Bean is a very popular and important vegetable crop in Bangladesh. Two-spotted spider mite (TSSM) attacks bean plants and cause great damage to the plant resulting yield loss (Gapud, 1981). It is essential to control TSSM for better and quality product. Increasing public concern about pesticide application and the widely recognized problem of pesticide resistance in mites have justified the need for alternative strategies for mite control. It has been reported that two-spotted spider mite populations have developed resistance against many chemicals (Helle \& Sabelis 1985, Herron et al., 1993; Takafuji et al., 2000). Development of resistance by TSSM to many acaricides has caused difficulties in controlling outbreaks by chemicals (Carbonaro et al., 1986). Biological control strategies for tetranychid mite pests include various techniques, like use of predators/parasites, mite pathogens, resistant varieties of host pants etc. Predation is an important component of ecological aspects because through predators the flow of energy continues throughout a community. It also regulates the populations on which they feed and maintain the fitness of these prey populations (Price, 1997).

The six-spotted thrips Scolothrips sexmaculatus Pergande is one of the predators of spider mite. The larva of this thrips are also active predator of spider mite. An adult S. sexmaculatus consumes about 10003000 T. urticae during its lifetime (Hoddle, 2004).

Phytoseiulus persimilis Athias Henriot is also an important predator of spider mite in various parts of the world (Battablia et al., 1990; Castagnoli \& Simoni 1999; Roy et al., 1999; Trumble \& Morse, 1993). This predaceous mite was accidentally introduced in Germany form Chili in 1958 (Dosse, 1958). From Germany, it was subsequently shipped to other parts of the world (Mc Murtry et al., 1978).

The smallest lady beetle Stethorus punctillum Weise is another active predator of TSSM. Due to its high voracity on TSSM, it is known as the mite destroyer. An adult can eat 75-100 mites per day (Raworth et al., 1998). Roy et al., (1999) reported $S$. punctillum as an effective predator of the Mc Daniel spider mite. It effectively reduced the high population of $T$. urticae infesting strawberry (Gracia Mari \& Gonzalez Zamora, 1998).

Some promising predators currently being evaluated as biological control agent against tetranychid mites. The predators attack and consume eggs, larva, pupae and adults of T. urticae. According to Strong and Croft (1995), predators must be released at a rate that provides a high predator prey ratio; the larger the predator prey ratio, the better the biological control through release of predators.

The present research was designed to control $T$. urticae population by available predators. The used predators are: Scolothrips sexmaculatus Pergande, Phytoseiulus persimilis Athias - Henriot and Stethorus punctillum Weise.

\section{Materials and Methods}

The experiment was conducted at three different times. Three different predators $S$. sexmaculatus, $P$. persimilis and S. punctatum were applied in September 2006, April 2007 and June 2007 respectively. For each predator fifteen bean seedlings were grown on clay pot in the premises of Department of Zoology, Rajshahi University. The bean seeds were bedded in the clay pot. The plants were allowed to grow on bamboo-made sticks at height of $1.5 \mathrm{~m}$ from the ground. The bean seedlings were nourished properly with fertilizers and water. The pots were arranged in three groups (Five pots in a group) as A, B and C. The pots of each group were separately covered by nets. Pots of A was considered as control and $\mathrm{B}$ and $\mathrm{C}$ as treated.

\section{Mite infestation}

The potted bean plants were infested with T. urticae when they were eight weeks old. The TSSM used for infestation was collected from laboratory culture, which 
was maintained on potted bean plants in the premises of the Department of Zoology, Rajshahi University for more than two years. Each plant was infested with 20 adult female mites. The mites were released on the bean leaves at $0.5 \mathrm{~m}$ height by placing the mite- containing plant parts on the host plant. All the 15 plants of three groups were infested with mites in similar way on the same day.

\section{Predator release}

The predators $S$. sexmaculatus, $P$. persimilis and $S$. punctatum used in this experiment were collected form bean plants of Rajshahi City Corporation area, where they appeared naturally. They were cultured on $T$. urticae on mite infested potted bean plants in the laboratory for more than six months in the Department of Zoology, Rajshahi University. The predators were released on the plants of group $B$ after one week of mite infestation and on the plants of group $\mathrm{C}$ after three weeks of mite infestation. On each plant 10 adult female predators were released of which five on the leaves at $\mathrm{lm}$ height and other five on the leaves at $1.5 \mathrm{~m}$ height for proper distribution. The predators were transferred on to the host leaf with the help of fine hairbrush.

\section{Counting}

Mite population was checked every week on all the plants of group $\mathrm{A}, \mathrm{B}$ and $\mathrm{C}$ continued up to the tenth week of mite infestation. In group $\mathrm{B}$, predator counting was started after one week of mite infestation. But in the group C, where predators were released after three weeks of mite infestation, predator counting was started from fourth week of mite infestation and continued up to tenth week. During each count 15 bean leaves were collected from each group. Mite and predator population were checked on both the surface of each leaf.

\section{Results and Discussion}

The mite population in three experiments treating with three different predators are shown in Figs. 1-3. The mite population remained higher on controlled plants where no predator was released. The mite number reached the peaks 409.26 (6th week, Fig. 1), 470.60 (10th week, Fig. 2), 679.20 (10th week, Fig. 3) per leaf in 1st, 2nd and 3rd experiment respectively.

With the release of $S$. sexmaculatus as predator to control mite, T. urticae population remained the highest 96.73 per leaf on which the predator was released after one week of mite infestation but it reached the highest 241.07 per leaf on which $S$. sexmaculatus was released after three week of mite infestation. But it reduced to only 24.00 and 43.33 per leaf in 8th and 9th week on early and late released plants respectively (Fig. 1).

T. urticae population remained the highest 37.93 per leaf in another experiment on which $P$. persimilis was released after one week of mite infestation but it reached the highest 113.60 per leaf on which $P$. persimilis was released after three week of mite infestation. But it reduced to only 8.73 and 22.93 per leaf in the 10th week early and late released plants respectively (Fig. 2). T. urticae population remained the highest 69.80 per leaf of bean where the predator, $S$. punctillum was released after one week of mite infestation.

But it reached 121.00 per leaf where S. punctillum was released after three week of mite infestation. But it reduced to 23.87 and 22.93 per leaf due to early and late release on 8 th and 10th week of mite infestation (Fig. 3).

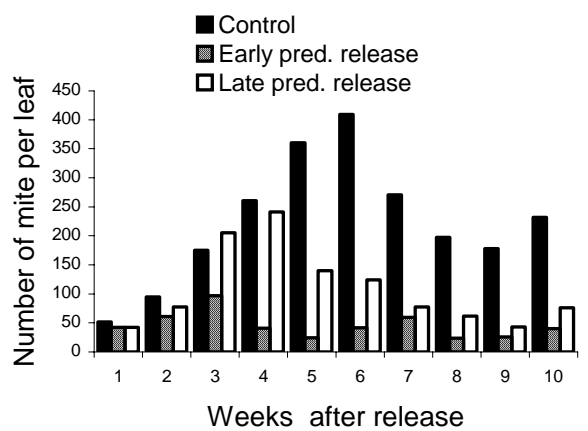

Fig.1. Effect of $S$. sexmaculatus on $T$. urticae population on potted bean plants.

On the untreated plants, mite population increased exponentially and caused damage to the plants. But on the predator treated plants, increase of mite population was checked and remained lower. The plants also remained fresh in comparison to untreated plants. Early release of predator checked the mite population earlier and kept it lower than on late released plants.

The predator population on different groups of bean plants are presented in Table-1. Predator number increased gradually in all cases with little exception. Predators number differed significantly among the types of predators $(\mathrm{F}=2.83 *, 20 / 9$, early release; $\mathrm{F}=5.90 * * *$, 20/9, late release).

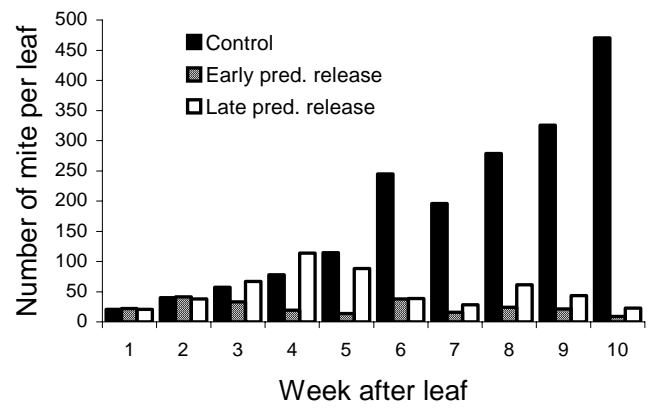

Fig. 2. Effect of $P$. persimilis on $T$. urticae population on potted bean plants. 
Research on the control of TSSM by different predators has been done widely in various parts of the world. S. sexmaculatus is an important predatory thrips of the family Thripidae and have been reported to suppress T. urticae populations. Shih (1999) reported that $S$. sexmaculatus primarily predated on TSSM eggs. Control of $T$. urticae by $S$. sexmaculatus has been also reported by Hoddle (2004).

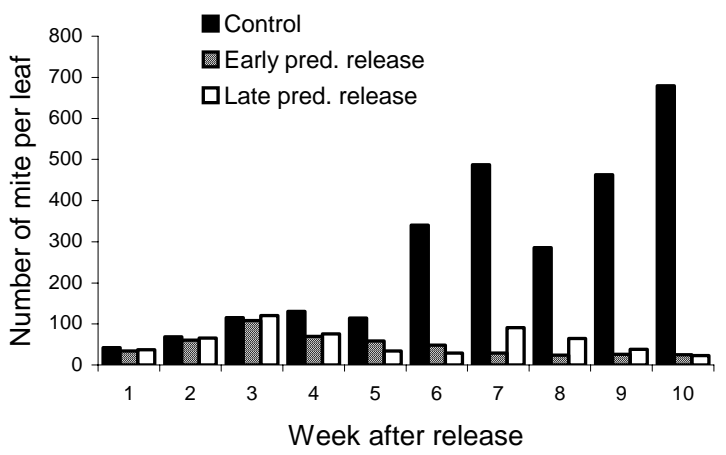

Fig.3. Effect of $S$. punctillum on number T. urticae opulation on potted bean.

Table-1. Number of different predators per leaf of potted bean plants.

\begin{tabular}{ccccccc}
\hline & \multicolumn{2}{c}{ S. sexmaculatus } & \multicolumn{2}{c}{$\boldsymbol{P}$. persimilis } & \multicolumn{2}{c}{ S. punctillum } \\
\cline { 2 - 7 } Weeks & $\begin{array}{c}\text { Early } \\
\text { release }\end{array}$ & $\begin{array}{c}\text { Late } \\
\text { release }\end{array}$ & $\begin{array}{c}\text { Early } \\
\text { release }\end{array}$ & $\begin{array}{c}\text { Late } \\
\text { release }\end{array}$ & $\begin{array}{c}\text { Early } \\
\text { release }\end{array}$ & $\begin{array}{c}\text { Late } \\
\text { release }\end{array}$ \\
\hline 1 & 0.00 & 0.00 & 0.00 & 0.00 & 0.00 & 0.00 \\
2 & 1.40 & 0.00 & 1.60 & 0.00 & 1.94 & 0.00 \\
3 & 6.20 & 0.00 & 2.47 & 0.00 & 2.47 & 0.00 \\
4 & 8.20 & 1.74 & 5.60 & 2.07 & 10.60 & 1.93 \\
5 & 4.33 & 8.07 & 6.86 & 3.20 & 10.40 & 9.94 \\
6 & 3.20 & 8.13 & 6.80 & 6.07 & 8.53 & 12.67 \\
7 & 3.60 & 6.87 & 6.13 & 5.60 & 6.13 & 6.00 \\
8 & 2.93 & 6.06 & 13.47 & 14.06 & 5.73 & 14.06 \\
9 & 5.13 & 8.47 & 10.53 & 11.20 & 14.80 & 23.20 \\
10 & 3.06 & 5.26 & 9.60 & 14.40 & 12.87 & 5.40 \\
\hline
\end{tabular}

P. persimilis is also important predatory mite of the family Phytoseiidae and have been reported to suppress $T$. urticae populations. $P$. persimilis can effectively reduce the number of acaricide applications by $87-92 \%$ in Crotons and $100 \%$ in Areca palms (Cashion et al., 1994). However, chemical applications were often necessary to decrease spider mite densities to acceptable levels, even after predator release (Helle \& Sabelis 1985). Trumble \& Morse (1993) reported that adequate suppression of $T$. urticae can be achieved by releasing $P$. persimilis in combinations with abamectin applications. In their study after threshold levels were surpassed, predator release combined with compatible acaricides was more effective than using chemical or biological control tactics alone $P$. persimilis and $S$. punctillum are being used in many countries as an alternative means to control two-spotted spider mite (Hoddle, 2004). Raworth et al. (1998) obtained an excellent result in controlling TSSM by releasing $S$. punctillum in tomato, pepper and cucumber in greenhouse in Canada.

The present experiment reveals that $T$. urticae increased exponentially upto the sixth week on controlled plants.. But on the plants where $S$. sexmaculatus were released, $T$. urticae population was checked effectively due to predation. Using $P$. persimilis and S. punctillum as predator, T. urticae population increased exponentially upto 10 th week in controlled plot. Due to predation of predators T. urticae population reduced to the minimum number. The early release of predator reduced the mite population earlier in all the case.

It may be concluded from the present investigation that all the three predators are effective against $T$. urticae and can be used as a bio-control agent of the pest.

\section{References}

Battablia, D., Borriello, G. \& Spicciarelli, R.D. 1990. Athias Henriot on protected strawbery in the Metapontum area, Informatore Ffitopatologica 40: 44-46

Carbonaro, M. A., Edge, E. N., Motoyama R.G.C. \& Dauterman, W.C. 1986. Studies on the mechanisms of cyhexatin resistance in the two - spotted spider mite, Tetranychus urticae (Acari: Tetranychidae), J. Econ .Ent. 79: 576- 579.

Cashion, G., Bixle, J.H \& Price J.F. 1994. Nursery IPM trials using predatory mites. Proc . Fla. state Hort. Soc 107:220-222.

Castagnoli, M. \& Simoni S 1999. Effect of long term feeding testing on functional and numerical response of Negeiulus californicus (Acari: Tetranychidae). Exp .Appl. Acarol. 23: 217-234.

Dosse, G. 1958. Ubereinigeneue Raubmibenarten (Acari: Phytoseiidae). Pflanzenchutzber. 21: 44-61.

Gapud, V. P. 1981. Insect and mite pest of plant crops in Bangladesh and their natural enemies. A ompendium for biological control in IPM. United States Agency for International Development Agriculture Research Council / Chechi and Company Consulting Inc. 265pp.

Garcia-Mari, F \& Gonzalez-Zamora, J. E. 1998. Biological control of Retrenches utricle (Acari: Tetranychidae) With naturally Occurring Predators in strawberry paintings in Valencia, Spain. Exp. Appl. Acarol. 23: 487-495.

Helle, W. \& Sabelies, M. W. (eds.) 1985. Spider mites: Their biology, natural enemies and control. Volume I part B. Elsevier, Amsterdam, 458pp. 
Herron, G., Edge, V. \& Rophalia, J. 1993. Clofentezine and hexythiazox resistance in Tetranychus urticae Koch in Australia. Exp. App, Acarol. 17: 433-440.

Hoddle, M. S. 2004. The biology and management of persea mite, Oligonychus perseae Tuttle, Baker and Abbatiello (Acari: Tetranychiodae). Department of Entomology, University of California, USA (internet) http://www.biocontrol. ucr.edu/mite1.html

McMurtry, J. A., Oatman, E. R., Phillips, P.A. \& Wood, C.W. 1978. Establishment of Phytoseiulus persimilis (Acari: Phytoseiidae) in Southern California. Entomophage 23: 175-179.

Price, P.W. 1997. Insect ecology, John Wiley and Sons, Inc. New York, 868pp.

Raworth, D. A., Whistlecraft, J. \& Gillespie, D. 1998. A lady beetle for mite control. Pest management News. 9(4): 11.

Roy, M., Brodeur, J. \& Clourtier, C. 1999. Seasonal abundance of spider mites and their predators on red raspberry in Quebec, Canada. Environ Entomol. 28(4): 735-747.
Shih, C.I.T. 1999. Population ecology and its application on tetranychid and phytoseiid mite. Chinese J. Entomol. 126: $25-45$.

Strong, W.B. \& Croft, B.A. 1995. Inoculative release of phytoseiid mites (Acarina: Phytoseiidae) into the rapidly expanding canopy of hops for control of Tetranychus urticae (Acarina: Tetranychidae). Environ. Entomol. 24(2): 446-453.

Takafuzi, A, Ozawa, A., Nemoto, H. \& Gotoh, T. 2000. Spider mites of Japan: Their biology and control. Exp. Appl. Acarol. 24: 319 -335.

Trumble, J.T. \& Morse, J.P. 1993. Economics of the integrating the predaceous mite Phytoseiulus persimilis (Acari :Phytoseiidae) with pesticides in strawberries. Hort, Entomol. 86: 879 - 885.

Manuscript received on 03.07.2008, accepted on 20.10.2008 